\title{
DEVICE-TO-DEVICE (D2D) COMMUNICATION PADA JARINGAN SELULAR
}

\author{
R. Purnama \\ Teknik Komputer, Fakultas Teknik, Universitas Wiralodra \\ rpurnama.ft@unwir.ac.id
}

\begin{abstract}
ABSTRAK
Didalam sebuah sistem telekomunikasi selular yang konvensional, perangkat-perangkat pengguna (UE) adalah tidak dimungkinkan untuk saling berkomunikasi secara langsung (direct communication) didalam bandwidth selular yang berlisensi. Semua komunikasi yang berlangsung harus melalui eNB atau base station (BS) sebagai jaringan inti (core network). Suatu kebutuhan untuk meningkatkan kapasitas jaringan dalam memenuhi permintaan-permintaan yang terus berkembang dari para pengguna telah membawa pada evolusi jaringan-jaringan telekomunikasi selular dari generasi pertama $(1 \mathrm{G})$ hingga generasi ke lima $(5 \mathrm{G})$. Sebuah metode baru $D 2 D$ Communication diperkenalkan dalam standar telekomunikasi selular konvensional terbaru LTE. Metode D2D Communication ini diantaranya diterapkan pada sistem radio keselamatan publik (public safety radio system). Dan saat ini, sistem radio keselamatan publik yang berbasis LTE tersebut sedang dipertimbangkan untuk digunakan karena dapat mengurangi biaya-biaya operasional dan pembangunan jaringan. Fungsi-fungsi komunikasi secara langsung dengan membypass eNB (tanpa melibatkan eNB) telah diperkenalkan didalam standar spesifikasi 3GPP Release 12 LTE-Advanced untuk sistem radio keselamatan publik sehingga komunikasi-komunikasi dapat disediakan bahkan jika sebuah eNB mengalami down (failure atau kerusakan) karena adanya suatu bencana dengan skala yang besar, gempa bumi atau tsunami dsb. Fungsi-fungsi Device Discovery yang memungkinkan D2D komersial juga diperkenalkan pada release 12 tersebut.
\end{abstract}

Kata Kunci: D2D Communication, Device Discovery, Public Safety Radio System

\section{ABSTRACT}

In conventional cellular communication system, user terminals (UEs) are not allowed to direct communicate in cellular licensed bandwidth. All communication are performed through eNB or base stations as a core network. A demand to increase network capacity to meet growing demands of the users have led to the evolution of cellular communication networks from the first generation $(1 G)$ to fifth generation $(5 G)$. A new method called D2D communication was introduced in the cellular LTE communication system. The method was among other thing being applied to public safety radio systems. Recently, LTE-based public safety radio systems are being considered to be used since it can reduce network deployment and operational costs. Direct communication functions that bypas eNB were introduced in the 3GPP LTE-Advanced Release 12 specification standard for public safety radio system. Communications can be provided even if an eNB is down due to a natural disaster such as earthquake, tsunami etc. Device discovery functions which allows commercial D2D were also introduced in the release 12.

Key Word: D2D Communication, Device Discovery, Public Safety Radio System 


\section{PENDAHULUAN}

Dengan banyaknya perangkat-perqngkat cerdas hand-held, kebutuhan-kebutuhan para pengguna untuk mobile broadband mengalami peningkatan yang sangat cepat. Perkembangan yang drastis dari aplikasiaplikasi yang haus bandwidth seperti misalnya video streaming dan multimedia sharing juga meningkat pada sistem-sistem selular saat ini. Kebutuhan yang terus bertambah untuk kapasitas dan rate data yang lebih tinggi memerlukan pemikiran yang tidak lagi konvensional untuk sistem-sistem telekomunikasi selular generasi selanjutnya (5G). Cooperative communication, yang merupakan suatu paradigma baru didalam teknik-teknik telekomunikasi wireless, menjanjikan hal itu. Pada metode transmisi ini, node-node yang berada didalam suatu jaringan yang multiuser, dapat saling berbagi (share), berkoordinasi (coordinate) dan bekerja sama (cooperate) dalam merelay suatu informasi [7]. Paradigma transmisi yang baru ini menjanjikan peningkatanpeningkatan performa yang signifikan dalam hal kehandalan link (link reliability), efisisnsi spectrum (spectral effeiency), kapasitas sistem (system capacity) dan jangkauan/cakupan transmisi (covaerage). Cooperative communication dan teknologi relay sendiri telah diadopsi didalam standard spesifikasi IEEE 802.16j dan standar 3GPP Release 10 LTE-Advanced [7].

D2D Communication, yang merupakan lanjutan dari metode sebelumnya, yaitu Cooperative Communication, memungkinkan dua perangkat-perangkat yang berdekatan untuk saling berkomunikasi didalam bandwidth selular yang berlisensi, baik tanpa pelibatan sebuah eNB (base station BS) ataupun dengan pelibatan eNB yang terbatas. Pada generasi yang pertama dari empat generasi jaringan-jaringan selular, fungsionalitas Cooperative Communication dan D2D Communication belum dipertimbangkan. Kedua metode transmisi ini baru mulai diadopsi didalam standar 3GPP Release 10 LTE-Advanced pada tahun 2011 dan 3GPP Release 12 LTE-Advanced pada tahun 2015. Fungsionalitas-fungsionalitas utama pada standar spesifikasi Release 12 dapat diklasifikasikan menjadi tiga kategori utama, yaitu: teknologi-teknologi baru untuk meningkatkan throughput pengguna, teknologi-teknologi baru untuk meningkatkan daerah cakupan (coverage) dan fungsionalitas yang ditingkatkan berdasarkan pada pengalaman-pengalaman operasi jaringan [9], seperti ditunjukkan pada gambar 1 dibawah.

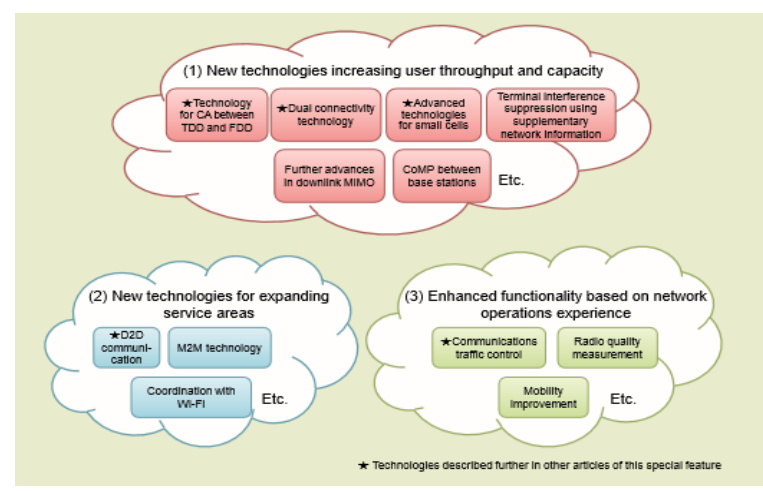

Gambar 1. Fungsionalitas utama pada standard 3GPP Release 12 [Nagata Satoshi et.al]

Fungsionalitas D2D dapat memainkan sebuah peranan yang vital didalam cloud computing mobile dan memfasilitasi sharing resources (spectrum, computational power, aplikasi-aplikasi dan konten-konten sosial) yang efektif untuk pengguna-pengguna (UE) yang berdekatan secara spasial satu sama lain. Service provider juga dapat mengambil keuntungan dari fungsionalitas D2D ini karena akan mengurangi beban jaringan didalam sebuah area lokal seperti misalnya sebuah stadion atau mall yang besar dengan memungkinkan transmisi langsung (direct transmission) diantara cell phones dan perangkat-perangkat lainnya. D2D communication juga dapat menjadi suatu penggunaan yg kritis didalam suatu kondisi karena adanya bencana alam. 


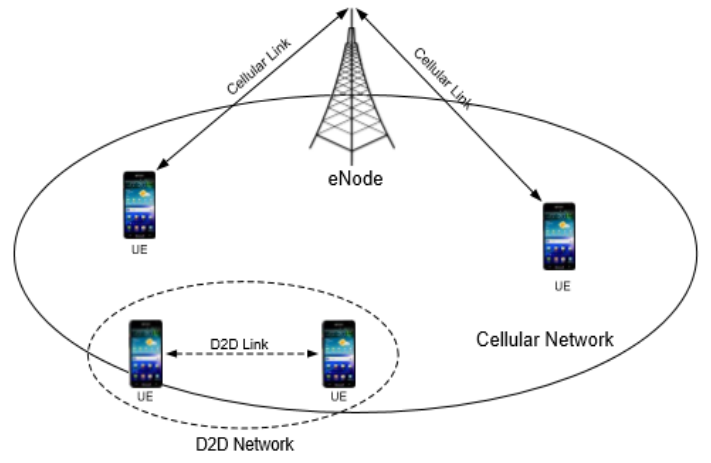

Gambar 2. D2D communication [Choi Sunghyun]

Seperti dijelaskan diatas, sistem radio keselamatan publik (umum) adalah metode komunikasi yang digunakan didalam situasisituasi yang darurat. Saat ini, sistem radio keselamatan publik yang berbasis LTE sedang dipertimbangkan untuk mengurangi biaya-biaya operasional dan biaya pambangunan jaringan, dan menyediakan komunikasi-komunikasi broadband dengan sistem tersebut. Sistem radio tersebut idealnya dapat menyediakan komunikasikomunikasi ketika sebuah eNB tidak dapat beroperasi karena suatu kondisi, seperti adanya bencana alam yang hebat, gempa bumi, tsunami dll., atau didalam area-area yang berada diluar cakupan (coverage) eNB seperti misalnya di daerah-daerah pegunungan atau perbukitan. Sebuah jaringan komunikasi yang mendesak dapat segera dibangun dengan menggunakan fungsionalitas D2D dalam jangka waktu yang cepat, menggantikan infrastruktur atau jaringan eksisting yg rusak akibat bencana alam tersebut (lihat gambar 2). Oleh karenanya, 3GPP telah merancang spesifikasi-spesifikasi untuk fungsi-fungsi D2D communication yang mem-bypass peran eNB. Juga penggunaan D2D komersial sedang dipertimbangkan untuk menyediakan Device-to-Device Proximity Service ProSe ${ }^{1}$

\footnotetext{
${ }^{1}$ Tujuan dari Proximity Service (ProSe) adalah untuk mengijinkan perangkat-perangkat yang berdekatan lokasinya (close proximity) untuk saling mendeteksi satu sama lain dengan tujuan untuk mengurangi beban
}

pada terminal-terminal yang berada disekitarnya, spesifikasi-spesifikasi dirancang untuk teknologi-teknologi Device Discovery diantara terminal-terminal yang berada disekitarnya. Maka seperti ditunjukkan pada gambar 3, dan eNB pada metode ini adalah optional.

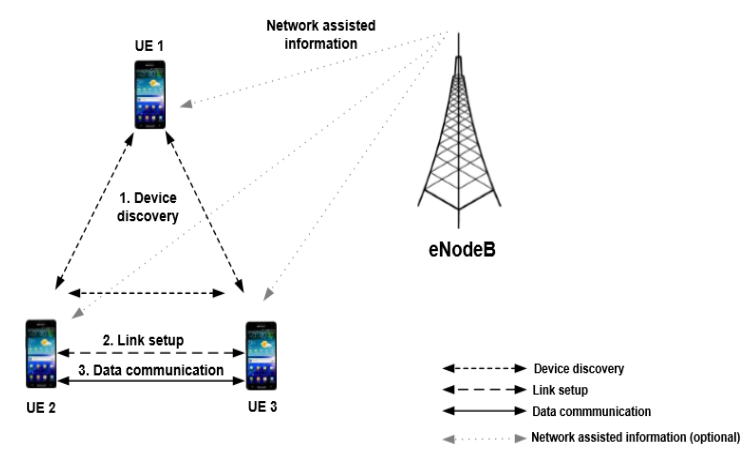

Gambar. 3 . Device discovery [Choi Sunghyun]

D2D Communications didalam sistem LTE terdiri dari dua fungsi, yaitu : Direct Communication dan Device Discovery. D2D Communications didalam LTE meliputi dua skenario, yaitu pertama autonomous D2D communication, diluar area-area cakupan eNB, dan yang kedua yaitu D2D Communications dengan bantuan eNB didalam area-area cakupan (coverage) eNB. Didalam skenario berikutnya, bantuan eNB memungkinkan komunikasi-komunikasi yang lebih efisien. Bagaimanapun, bahkan jika bantuan eNB adalah tersedia, didalam $D 2 D$ Communications data adalah ditransmisikan dan diterima secara langsung diantara terminal-terminal tanpa melalui eNB atau base station (BS) sebagai jaringan inti (core network). Selanjutnya, untuk penggunaan frekwensi yang efektif dan untuk meminimalkan implementasi tambahan yang diperlukan oleh terminal-terminal eksisting, D2D Communications didalam LTE akan

jaringan, meningkatkan kapasitas didalam sebuah bandwidth yang diberikan dan mengijinkan komunikasi di area-area tanpa cakupan jaringan (network coverage). 
menggunakan sebuah subset dari sumber radio-sumber radio.

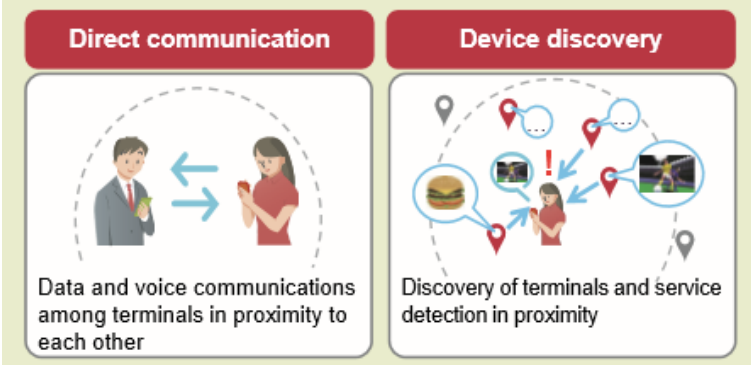

Gambar 4. Direct communication dan Device directory [Yasukawa Shinpi et al.]

\section{METODE PENELITIAN}

Sampai saat ini, tipikalnya ada dua sistem komunikasi yang digunakan, yaitu yang pertama untuk melayani kebutuhan komunikasi komersial seperti halnya pada sistem komunikasi selular, dan yang kedua adalah untuk melayani kebutuhan komunikasi kritikal seperti misalnya komunikasi untuk keselamatan publik. Ada bermacam-macam metode untuk sistem komunikasi keselamatan publik yang digunakan diseluruh negara. Banyak negaranegara mempunyai sistem-sistem yang berbeda dan dibangun secara independen oleh organiasi mereka, misalnya saja di Amerika dan sebagian Asia menggunakan sistem Project25 sementara di Eropa sebagian besar menggunakan sistem TETRA. Sistem komunikasi keselamatan publik ini misalnya digunakan pada badan-badan seperti kepolisian dan pemadam kebakaran, yang berarti ada tantangan untuk deployment jaringan, mengurangi biaya-biaya operasi jaringan dan meningkatkan interoperability diantara badan-badan pemerintah dan layanan-layanan emergency mereka. Oleh karenanya , banyak negara-negara kemudian mempertimbangkan untuk mengalihkan jaringan keselamatan publik eksisting (P25/APCO-25 dan TETRA) ke jaringan LTE karena LTE menawarkan banyak keuntungan-keuntungan, dainataranya yaitu : biaya-biaya terminal dan jaringan yang lebih rendah, biaya-biaya yang lebih rendah melalui sharing fasilitas-fasilitas jaringan LTE komersial, interoperability yang dijamin oleh standar spesifikasi-spesifikasi dan komunikasi-komunikasi broadband.

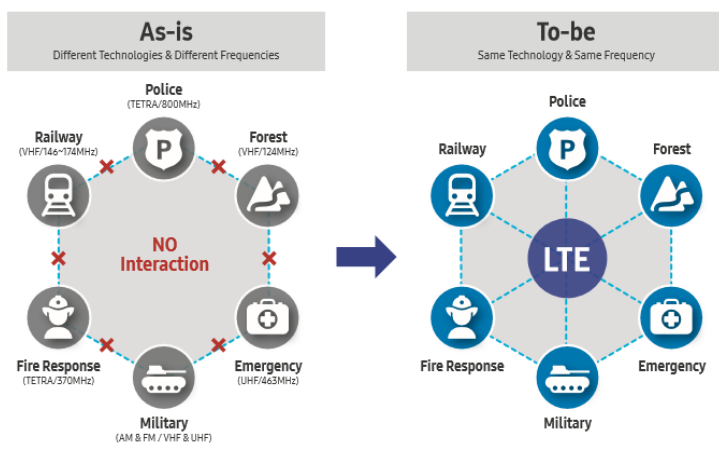

Gambar 5. LTE untuk keselamatan public [SAMSUNG NETWORKS]

Pada penelitian ini, pengumpulan data dan atau informasi menggunakan metode sebagai berikut, yaitu berupa kajian pustaka dan pengumpulan data dan informasi dari berbagai sumber-sumber informasi seperti : standard-standar spesifikasi yang diterbitkan oleh 3GPP sebagai badan standarisasi, technical journal dan juga artikel-artikel yang terkait dengan judul dari penelitian ini. Kemudian dari hasil kajian pustaka dan pengumpulan sumber-sumber informasi dan data dari berbagai sumber tersebut, maka dilakukan analisa dan pembahasan yang lebih mendalam untuk mendapatkan hasil dan kesimpulan. Pembahasan pada penelitian tentang metode transmisi D2D Communication ini lebih difokuskan pada sistem radio keselamatan publik (public safety radio system) yang rencananya akan digunakan sebagai fitur tambahan pada sistem jaringan komunikasi LTE. Meskipun masih berupa kajian, akan tetapi pembahasan tentang D2D Communication ini menarik perhatian banyak pihak, baik para peneliti, akademisi dan operator-operator jaringan telekomunikasi dibanyak negara. Merekapun berpartisipasi aktif didalam proses standarisasi didalam badan-badan standarisasi seperti 3GPP diatas. 
Harapan penulis, semoga penelitian tentang metode transmisi baru ini bisa menjadi pengetahuan baru bagi para pembaca terutamanya bagi para mahasiswa pemula yang saat ini sedang mendalami bidang ilmu telekomunikasi dan informasi.

\section{HASIL DAN PEMBAHASAN}

Dalam merespon serangan teroris tanggal 11 September, Amerika membuat sebuah keputusan untuk membangun sebuah jaringan keselamatan publik (public safety) berbasis LTE yang berskala nasional pada tahun 2012 [9]. D2D Communication terutamanya Direct Communication akan digunakan sebagai tambahan pada komunikasi selular dalam sistem-sistem LTE keselamatan publik. Spektrum frekwensi untuk sistem-sistem LTE keselamatan publik didiskusikan oleh International Telecommunication Union Radiocommunication Sector (ITU-R) sebagai keselamatan publik broadband, Public Protection and Disaster Releief (PPDR) seperti yang direncanakan untuk penggunaan di US dan Korea.

D2D Communication untuk tujuan komersial juga banyak menarik perhatian pada tahun-tahun belakangan ini termasuk bermacam-macam Device discovery dan fungsi-fungsi komunikasi seperti misalnya Bluetooth Low Energy (BLE)-enable iBeacon, Wi-Fi Aware, fungsi-fungsi yang mendukung transmisi beacon (data ID ditransmisikan melalui udara) untuk menemukan perangkat-perangkat didalam lingkungan sekitar (vicinity). Pada umumnya, tipe Device Discovery memungkinkan user $I D$ dan ID tersebut bersesuaian dengan user interest information yang tertanam didalam beacon tersebut untuk memungkinkan bermacam-macam layanan. Sebagai contoh, teknologi ini dapat diaplikasikan pada sharing economy yang banyak mendapatkan perhatian pada tahun-tahun belakangan ini untuk berbagi dan bertukar layanann, produk atau dana moneter yang berdasarkan lokasi dari user tersebut atau interest-interest mereka. Sistem-sistem ini juga memungkinkan layanan-layanan seperti misalnya distribusi iklan lokal (local advertising distribution) pada terminalterminal didalam area tersebut, pemandu lokal (local guidance) untuk para turis atau memantau hewan peliharaan dari jauh (remote pet monitoring) [9]. Layananlayanan Direct discovery berbasis LTE ini dapat menyediakan komunikasi yang stabil dalam suatu jangkauan yang luas dari areaarea komunikasi (lihat gambar 6 dibawah).

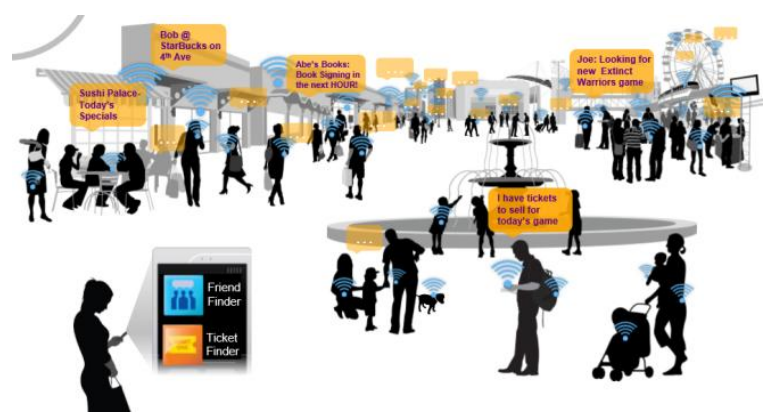

Gambar 6. Direct LTE [Balraj Sajith]

\subsection{Arsitektur Jaringan D2D}

Gambar 7 dibawah ini menunjukkan sebuah contoh dari arsitektur D2D LTE [9]. Sebuah terminal UE yang berada didalam area cakupan (coverage) berinteraksi dengan fungsi ProSe, yang merupakan sebuah fungsi lojik didalam Evolved Packet Core (EPC) untuk D2D. Fungsi ProSe mengautentikasi terminal tersebut dengan menggunakan Home Subscriber Server (HSS), sementara SLP (Secure User Plan Location (SUPL) Location Platform) adalah digunakan untuk mendistribusikan seting-seting komunikasi yang tepat. 


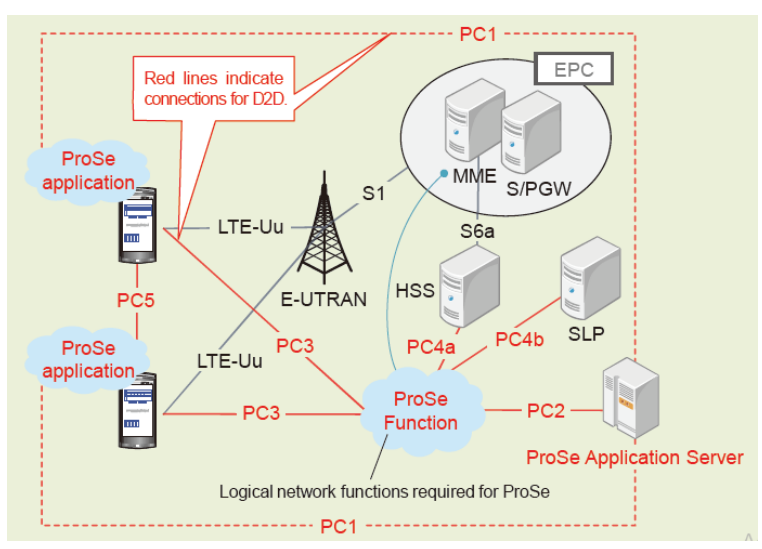

Gambar. 7. Arsitektur jaringan [Yasukawa Shinpi et al.]

Fungsi ProSe memungkinkan konfigurasi-konfigurasi yang perlu untuk komunikasi-komunikasi diluar coverage area. Seting-seting untuk komunikasi-komunikasi diluar area-area cakupan (coverage) adalah berkaitan dengan region yang melarang pengiriman (transmission) dan pnerimaan didalam area-area cakupan dimana regulasi tidak mengijinkannya. Juga dengaan memanage security keys dengan jaringan, level-level yang tinggi dari security diperlukan untuk layanan-layanan seperti misalnya group calling dapat di pastikan. Selain dari konfigurasi ini melalui jaringan tersebut, ada juga metode-metode untuk preconfigure seting-setting didalam terminalterminal atau kartu-kartu Subscriber Identity Module (SIM). Didalam area-area cakupan, sebagai tambahan terhadap konfigurasikonfigurasi yang ditransfer dari fungsi ProSe, parameter-parameter radio $\mathrm{D} 2 \mathrm{D}$ adalah diindikasikan dari eNB. Lebih jauh lagi, EPC ProSe user IDs dan ProSe function IDs adalah disimpan di ProSe Application Server yang juga berasosiasi dengan user IDs pada application layer dengan EPC ProSe User ID. Terminal-terminal adalah di-enable untuk Direct Communication dan Device discovery, Setelah setting parameter-parameter diluar coverage ini atau konfigurasi dari eNB didalam area-area coverage. Bagaimanapun, Direct discovery area-area diluar cakupan (coverage) adalah tidak disupport didalam
Release 12, meskipun diskusi-diskusi mengenai hal tersebut dilakukan.

\subsection{Struktur Dasar Layer 1 dan Layer 2}

Berikut ini adalah struktur dasar dari Physical Layer (Layer 1) dan Media Access Control MAC (Layer 2). Sebuah subset dari sumber-sumber radio uplink dari komunikasikomunikasi selular adalah digunakan untuk D2D Communication, sementara kanal-kanal fisiknya adalah distrukturkan seperti pada gambar 8 dibawah. Berikut ini menggambarkan bermacam-macam sinyal, kanal-kanal dan penggunaannya.

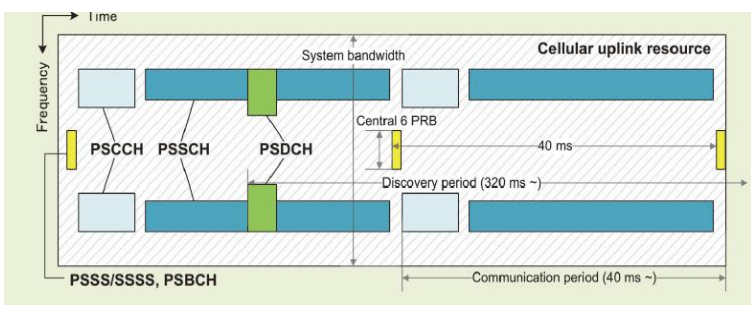

Gambar. 8. Struktur kanal D2D [Yasukawa Shinpi et al.]

\subsubsection{Seting Sinkronisasi}

\section{A. Area-Area Coverage di dalam eNB}

Didalam area-area cakupan (coverage) $\mathrm{eNB}$, pengiriman dan penerimanan D2D adalah dilakukan pada sinkronisasi dengan Primary/Secondary Synchronization Signal (PSS/SSS) yang adalah merupakan sinyal sinkronisasi yang ditransmisikan oleh eNB. Selain daripada beberapa kekecualiankekecualian, D2D transmission timing adalah PSS/SSS reception timing, dan Timing Advance (TA) yang digunakan dengan transmisi pada uplink selular adalah tidak diaplikasikan.

B. Area-Area Coverage di luar eNB

Primary/Secondary

Sidelink $^{2}$ Synchronization Signals

(PSSS/SSSS)

\footnotetext{
2 Didalam terminology LTE, link (UE ke UE) dinamakan sebagai sidelink, berlawanan dengan
} 
ditransmisikan oleh terminal pengguna (UE) didalam atau diluar area-area coverage adalah ditentukan sebagai sinyal-sinyal untuk sinkronisasi antara terminal-terminal D2D diluar area-area coverage eNB. Serupa dengan PSS/SSS, PSSS/SSSS juga menggunakan Zadoff-Chu sequences dan $M$ sequences secara berturut-turut yang dikirimkan pada interval-interval 40 ns dengan menggunakan pusat dari bandwidth sistem. Seperti ditunjukkan pada gambar 9, ketika sebuah UE adalah berada didalam sebuah area coverage mengirimkan PSSS/SSSS berdasarkan pada eNB sync timing, UE diluar area coverage dapat juga melakukan Direct Communication dengan eNB sync timing [9].

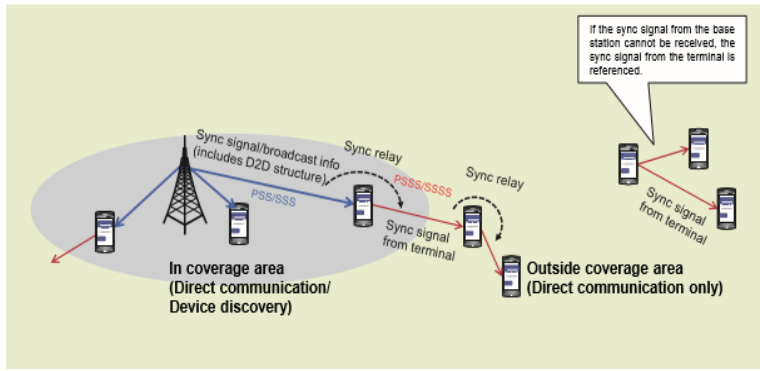

Gambar 9 . Sync timing relay dengan komunikasi2 diantara terminal2 yang berada didalam dan diluar cakupan [Yasukawa Shinpi et al.]

Didalam Direct Communication, D2D frame number, system bandwidth dan Time Division Duplex (TDD) UL/DL subframe configuration dst., adalah ditransmisikan oleh Physical Sidelink Broadcast Control Channel PSBCH ${ }^{3}$ juga PSSS/SSSS. Bahkan dengan Device discovery yang hanya support di area-area coverage, PSSS/SSSS dapat digunakan untuk sinkronisasi diantara UE dalam sel-sel yang berbeda.

\subsubsection{Parameter-Parameter Radio}

terminologi konvensional selama ini seperti uplink (UE ke eNB) dan downlink (eNB ke UE).

${ }^{3}$ PSBCH adalah kanal yang membawa sinyal-sinyal sinkronisasi dan informasi sistem.
Parameter-parameter radio adalah diberitahukan didalam informasi broadcast dari eNB didalam area-area coverage. Sebagai contoh, pemberitahuan ini termasuk PSSS/SSSS configurations, candidate time dan frequency resources (resources pool) yang digunakan untuk pengiriman dan penerimaan Physical Sidelink Control Channel $\mathrm{PSCCH}^{4}$, Physical Sidelink Shared Channel $\mathrm{PSSCH}^{5}$,. Dan Physical Sidelink Discovery Channel PSDCH $^{6}$ dst. UE diluar area-area coverage menggunakan preconfigured parameters untuk D2D.

\subsection{Direct Communication}

PSCCH dan PSSCH yang didefinisikan dengan siklus komunikasi ProSe (msal $40 \mathrm{~ms}$ cycle) adalah digunakan didalam Direct Communication. Serupa dengan uplinks, untuk mencapai Peak to Average Power Ratio (PAPR) yang rendah didalam kedua kanal, sebuah struktur sinyal berbasis pada Physical Uplink Shared Channel (PUSCH) digunakan. PSCCH adalah sebuh kanal kendali (control) yang menginginformasikan scheduling untuk data yang dikirimkan dengan PSSCH dan bagian dari ID tujuan layer 2. PSSCH adalah sebuah kanal data yang dishared untuk Direct Communication. Dengan mengirimkan Multiple Media Access Control Protocol Data Units (MAC PDU) didalam serial pada siklus komunikasi PsoSe, pengiriman single control data $\mathrm{PSCCH}$ memungkinkan transmisi-transmisi multiple MAC PDU, yang mengurangi overhead karena control signalling terutama dengan komunikasi-komunikasi suara.

Alamat ID yang diattach pada layer 2 header adalah didefinisikan untuk

\footnotetext{
$4 \quad$ PSCCH adalah kanal yang membawa (UE keUE) control plane data.

5 PSSCH digunakan untuk transmisi user plane data.

${ }^{6}$ PSDCH adalah kanal yang mensupport transmisi discovery langsung UE
} 
Unicast/Groupcast/Broadcast secara berturut-turut. Berbeda dari komunikasikomunikasi selular yang konvensional, ini mencapai filtering penerimaan pada layer 2 . Juga Diret Communication tidak support suatu kanal feedback yang didefinisikan didalam physical layer sementara banyak fungsi-fungsi seperti misalnya transmisi ACKnowledgement (ACK) / Negative ACK (NACK) adalah dijaga di layer-layer yang lebih atas.

\subsection{Device Discovery}

Device discovery menggunakan PSDCH yang didefinisikan dengan ProSe discovery cycle (misalnya $320 \mathrm{~ms}$ cycle), sementara UE mengirimkan Discovery Messages secara periodik atau berkala. Struktur sinyal adalah berdasar pada PUSCH dengan cara yang sama seperti PSCCH/PSSCH. Berbeda dari Direct Communication, informasi control seperti PSCCH adalah tidak dikirim dengan Device Discovery, tetapi UE yang sedang menerima secara langsung mendeteksi Discovery Message didalam PSDCH resource pool dan melakukan filter penerimaan pada layer aplikasi berdasar pada isi konten didalamnya user interest informations. Pada umumnya, karena konten dari Discovery Messages tidak sering dirubah, siklus ProSe Discovery adalah diset agak panjang, berkisar dari $320 \mathrm{~ms}$ hingga 10.24 s. Pengiriman dan penerimaan Discovery Message adalah dilakukan untuk semua UE dengan sync di dalam sell untuk PSS/SSS yang dikirim oleh eNB didlam area coverage, yang memungkinkan suatu duty ratio yang rendah (Discovery Message Transmission Time Ratio) yang mencapai efek-efek seperti misalnya overhead dan pengurangan konsumsi daya terminal.

\subsection{Aplikasi-Aplikasi D2D}

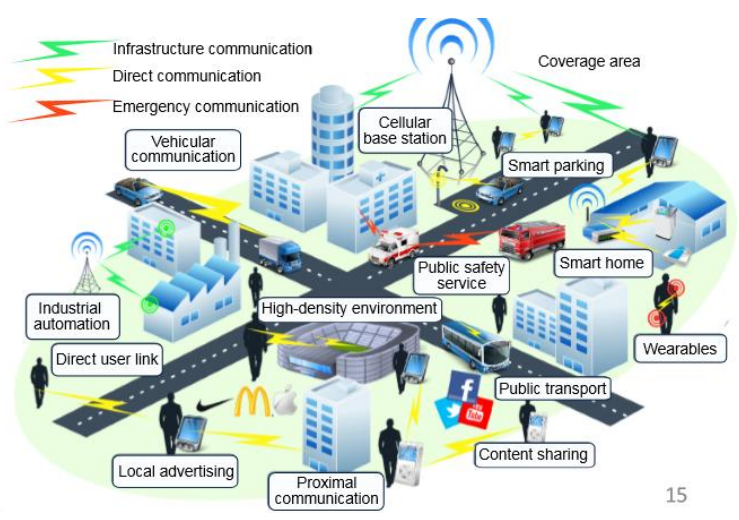

Gambar 10. Aplikasi-aplikasi D2D communication [Ometov Alexandr]

\section{KESIMPULAN}

D2D Communication diperkenalkan didalam standar spesifikas 3GPP Release 12 LTE-Advanced dan sistem radio keselamatan publik (public safety radio system) adalah merupakan aplikasi dari $D 2 D$ communication tersebut. Sistem radio keselamatan publik merupakan metode komunikasi yang digunakan selama dalam keadaan darurat atau emergency. Banyak negara-negara yang berencana untuk menggantikan sistem radio keselamatan publik eksistting (Project25 dan TETRA) dengan sistem radio keselamatan publik berbasis jaringan komunikasi selular LTE. Sementara itu, D2D yang berbasis LTE tersebut juga mendukung Device Discovery yang akan memungkinkan layanan-layanan untuk pendistribusian informasi terhadap terminal-terminal didalam proximity area (yang berada disekitarnya). Metode D2D Communication ini banyak menarik perhatian, baik dari para peneliti, akademisi, vendor-vendor maupun operator-operator telekomunikasi di banyak negara. Dan diskusi-diskusi atau kajian tentang perluasan fungsi-fungsi keselamatan publik dari D2D pada Release 12 tersebut pun masih berlanjut hingga saat ini. Dan diantisipasi bahwa metode D2D Communication ini akan memainkan sebuah peranan yang sangat penting didalam merespon terhadap permintaan-permintaan untuk layanan 
komunikasi broadband dengan rate yang tinggi dimasa mendatang.

\section{DAFTAR PUSTAKA}

[1] Balraj Sajith. 2012. LTE Direct Overview.Qualcom Research, Slide ppt.

[2] Choi Sunghyun. D2D Communication.

Soul National University. Slide ppt.

[3] Liebhart Rainer. 2015. LTE for Public Safety. Nokia Networks. Slide ppt.

[4] Madhusudhanan N., Venkateswari R dan Abraham Ajun. 2017. Cooperative Communication for 5G Networks : A Green Communication Based Survey. International Journal of Information Science and Computing. Hal. 65-78.

[5] Nagata Satoshi, Takeda Kazuaki dan Takahashi Hidaki. 2015. LTEAdvanced Release 12 Standardization Technology Overview. NTT DOCOMO Technical Journal. Volume 17 (2), hal. 31-35.

[6] Ometov Alexandr. 5G Vision and D2D Communications. Tampere University of Technology. Slide ppt.

[7] Purnama R. 2018. Aplikasi Cooperative Relaying Pada Teknologi LTE-Advanced dan Prospeknya di Indonesia. Jurnal TEKNOKOM. Volume 1 (01). Hal. 23-38.

[8] Tehrani Mohsen Nader, Uysal Murat dan Yanikomeroglu Halim. 2014. Device-to-Device Communication in 5G Cellular Networks : Challenges, solutions and Future Directions.IEEE Communication Magazine. Hal. 86-91.

[9] Yasukawa Shinpi, Harada Hiraki, Nagato Satoshi dan Zhao Qun. 2015. D2D Communications in LTEAdvanced Release $12 . \quad$ NTT DOCOMO Technical Journal. Volume 17 (2). Hal. 56-64.

[10] Public Safety LTE Solution :For a Reliable, Fast and Secure Network. SAMSUNG NETWORKS. 2016. 
Halaman ini sengaja dikosongkan 